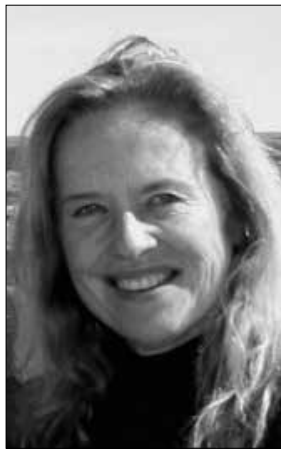

https://doi.org/10.24101/logos.2017.48

Gauta 20170902

VIDA SAVONIAKAITÉ

Lietuvos istorijos institutas

Lithuanian Institute of History

\title{
SKIRTYS IR BENDRUMAI
}

Europoje iškyla naujų akademinių aktualijų: „savas" ir "kitas" visuomenèje sukelia didelių problemų, konfliktu, ìvairiausių kultūros pokyčių, migracijų srautus. Akademinei bendruomenei svarbu identifikuoti "lokalius" ir "globalius" šių sąvokų aspektus, diskutuoti apie mokslines teorines prieigas ir kartu atskleisti lituanistikos bruožus. Šiuolaikiniu antropologijos ir etnologijos teorijų požiūriu "savas" ir "kitas" naujai tyrinėjami kaip vienos pliuralistinės visuomenės reiškiniai. Siekiama analizuoti ne tik priešpriešą "savas / svetimas", o įvairiapusį tapatybès "keitimąsi“ (G. Bauman, A. Gingrich, N. Rapport, V. Savoniakaitè). "Savas" ir "kitas" kaip mokslinės sampratos ir gyvenimo realijos įkvepia projekto idèją - naujai pažvelgti i socialinės teorijos klasikinę Gemeinschaft / Gesellschaft prieštarą.

Logos žurnalo straipsniuose siekiame palyginti kontekstus, kuriuose "savas" ir "kitas" yra susiję su visiškai naujais tarptautiniais procesais, valstybės vaidmeniu, nacionalizmu ne tik Lietuvoje, bet ir Europoje. Atskleisime, kaip etniškumas, tarsi šerdis, leidžia suprasti etninių bendruomenių, tautų išskirtinius bruožus. Aptarsime, ar tautinè, pilietinė tapatybė išryškèja ir pinasi tarp kitu žmogaus tapatybių ir ypatybių, mokslo istorijoje žinomų jau Gemeinschaft / Gesellschaft tradicijose. Nagrinėsime priklausomybę bendruomenei, tautai, kultūrai ir regionui.

Šio žurnalo kelių numerių skyriuose kritiškai svarstysime žmonių "skirčių" ir "bendrumų" (1) teorines, (2) „kintančias" kultūrines, socialines reikšmes ir (3) iššǔkius šiuolaikinei visuomenei. Sampratų Gemeinschaft / Gesellschaft teorinius skirtumus mieste ir kaime analizuos Christianas Giordano ir Irma Šidiškienè. Istorinius bendruomenių nacionalizmo ir kultūros raidos problematikos naratyvus aptars Vladislavas B. Sotirovićius ir Anna Gomóła. Migracijos iššūkius šiuolaikinės priklausomybės tautai sampratoms, tapatybėms ir kultūrai Lietuvoje bei toliau atskleis Vida Savoniakaitė, Laura Laurušaitė, Darius Daukšas ir Vytautas Tumėnas. Tai Lietuvos istorijos instituto vykdomos mokslinių tyrimų programos Etniškumo ir nacionalumo pažinimas (2017-2021, www.istorija.It) dalis. Straipsniai parengti remiantis tarptautinėje konferencijoje Skirtys ir bendrumai kultūriniuose ir socialiniuose kontekstuose (konferenciją rẻmė Lietuvos mokslo taryba, projekto finansavimo sutartis Nr. LIP-106/2016) Lietuvos istorijos institute 2016 m. rugsèjo 22-23 d. skaitytais pranešimais ir naujais tyrimais.

Lietuvos mokslo istorijoje etnologijos tyrimuose daugiausia buvo domimasi "savos“ tautos, krašto, sovietmečiu - kultūros analize. "Savo" ir "kito" sampratos kaip „skirtys" ir "bendrumai“ nagrinėti mažai. Kitoniškumas ar kitas, susiję su šiuolaikinėmis mokslo ir gyvenimo aktualijomis (R. Merkienė, C. Giordano, U. Kockelis, A. Čepaitienė, V. Čiubrinskas, J. Kuznecovienè, N. Klumbytė, A. Putnina) kelia daug naujų teorinių, kultūrinių 
ir socialinių klausimų tarpdalykiniu požiūriu. Humanitariniuose ir socialiniuose moksluose užsienyje aktualijos "mes" ir "jie" naujai suvokiami kaip bendruomenès ir individo, kartu ir tautos "keitimasis“, tyrinejjamas ju saugumas, neapibrèžtumas ir kt. (T. H. Eriksenasas, U. Hannerz, P. Werbner, M. Banksas).

Nuoširdžiai dèkojame žurnalo Logos vyriausiajai redaktorei Daliai Marijai Stančienei, patikèjusiai šiomis mūsų idejjomis ir publikavusiai straipsnius.

\section{Dichotomies and Shares}

Anthropological and ethnological questions about the 'Self' and the 'Other' draw on distinctiveness and otherness, on dichotomies and shares and their interrelationships, on aspects of the consolidation and integration of society and concerns with collective and individual identities, on nationalism, on the homogenizing factor of the State and processes of globalisation, and many other issues that are on the agenda in a variety of contexts today. The separation between 'we' and 'they' we often understand as 'alterity within' community (G. Bauman, A. Gingrich, N. Rapport, V. Savoniakaitė) and etc. The contemporary reality makes it explicit that the 'Self' and the 'Other' are not only approaches to cultural and social classification applied by researchers, but also a part of the actual human life that invites us to return critically to the classics of social theory - the dichotomy of Gemeinschaft/Gesellschaft.

We argue that the 'other' and the 'different' that appear unexpectedly in contemporary contexts of the quotidian space, the flow and the amount of movements of people that extend the scale of migration showed once again the most important cultural and social aspect of human existence - differences that separate and similarities that unite.

The parts of Logos volumes seeks to discuss critically representations of 'dichotomies' and 'shares' in human life, European communities and Lithuanian nation as (1) theoretical approaches, (2) alter cultural and social meanings, and (3) challenges to contemporary society. The dichotomy of urban and rural Gemeinschaft/Gesellschaft are analysed in the articles of Christian Giordano and Irma Šidiškienė. Vladislav B. Sotirović and Anna Gomóła discover the historical narratives of a community's issues of nationalism and culture. Challenges of migration to contemporary society in Lithuania and abroad are discussed in the articles of Vida Savoniakaitė, Laura Laurušaitė, Darius Daukšas, and Vytautas Tumėnas.

These Logos volumes publish articles based on presentations in the international conference of the Lithuanian Institute of History, Dichotomies and Shares in Cultural and Social Contexts, 22-23 September, 2016 (sponsor: Research Council of Lithuania, project Contract No. LIP-106/2016) and our new research results working on the programme Cognition of Ethnicity and Nationalism (2017-2021, www.istorija.It).

The authors would very like to thank the chief editor of Logos, Dalia Marija Stančienė, for her support of our ideas and for her advice. 